Jurnal Sains Peternakan Nusantara

Volume 01 Nomor 02 Desember 2021

\title{
PERTUMBUHAN RUMPUT ODOT DI BAWAH PENGARUH KOMBINASI PUPUK
}

\author{
Adi Fathul Qohar ${ }^{\text {a }}$, Bahrun ${ }^{\mathrm{b}}$, Nur Hidayat ${ }^{\mathrm{c}}$ dan Nunur Nuraeni ${ }^{\mathrm{d}}$ \\ ${ }^{a, d}$ Program Studi Peternakan, Universitas Ma'arif Nahdlatul Ulama Kebumen, Kebumen \\ ${ }^{b, c}$ Fakultas Peternakan, Universitas Jenderal Soedirman, Purwokerto \\ adifathulqohar@umnu.ac.id
}

\begin{abstract}
ABSTRAK
Penelitian bertujuan untuk mengkaji pengaruh pemberian kombinasi level pupuk kandang dan NPK yang optimum ditinjau pertumbuhan yakni tinggi tanaman dan jumlah daun rumput odot. Materi yang digunakan dalam penelitian adalah tanaman rumput odot defoliasi ke-3 yang awalnya ditanam pada total lahan seluas $278 \mathrm{~m}^{2}$ dengan luas setiap petak atau unit adalah $5 \mathrm{~m}^{2}$ serta jarak tanam 0,75 $\mathrm{m} \times 0,35 \mathrm{~m}$ sehingga dibutuhkan 720 batang stek rumput odot, $270 \mathrm{~kg}$ pupuk kandang, $2,5 \mathrm{~kg}$ pupuk NPK. Metode yang digunakan adalah eksperimen pola faktorial dengan Rancangan Acak Kelompok. Faktor pertama adalah pupuk kandang yang terdiri dari $\mathrm{K}_{0}$ : pupuk kandang $0 \mathrm{~kg} / 5 \mathrm{~m}^{2}$, $\mathrm{K}_{1}$ : pupuk kandang $7,5 \mathrm{~kg} / 5 \mathrm{~m}^{2}, \mathrm{~K}_{2}$ : pupuk kandang $15 \mathrm{~kg} / 5 \mathrm{~m}^{2}$ dan faktor kedua adalah pupuk NPK (M) yang terdiri dari $\mathrm{M}_{0}$ : pupuk NPK $0 \mathrm{~g} / 5 \mathrm{~m}^{2}, \mathrm{M}_{1}$ : pupuk NPK $37,5 \mathrm{~g} / 5 \mathrm{~m}^{2}, \mathrm{M}_{2}$ : pupuk NPK 75 $\mathrm{g} / 5 \mathrm{~m}^{2}$ dan $\mathrm{M}_{3}$ : pupuk NPK $112,5 \mathrm{~g} / 5 \mathrm{~m}^{2}$. Peubah pertumbuhan yang diukur adalah tinggi tanaman dan jumlah daun rumput odot defoliasi ke-3. Hasil analisis variansi menunjukan bahwa interaksi antara kombinasi pupuk kandang dan NPK berpengaruh tidak nyata $(\mathrm{P}>0,05)$, sedangkan pemberian pupuk kandang berpengaruh sangat nyata $(\mathrm{P}<0,01)$ terhadap tinggi tanaman dan jumlah daun rumput odot, pemberian pupuk NPK berpengaruh nyata $(\mathrm{P}<0,05)$ terhadap tinggi tanaman dan jumlah daun rumput odot. Pengaruh tunggal pupuk kandang dan NPK dapat meningkatkan tinggi tanaman dan jumlah daun secara signifikan. Perlakuan interaksi pupuk kandang dan NPK tidak memberikan pengaruh yang signifikan terhadap tinggi tanaman dan jumlah daun rumput odot.
\end{abstract}

Kata kunci: rumput odot, pupuk kandang, NPK, pertumbuhan

\section{ABSTRACT}

The purpose of the study was determined the optimum level of manure and NPK combination in terms of growth namely, wheight plant and number of leaves of dwarf grass. The material used in the study was the third defoliation dwarf grass plant which was initially planted in a total area of $278 \mathrm{~m}^{2}$ with an area of each plot or unit of $5 \mathrm{~m}^{2}$ and a spacing of $0.75 \mathrm{mx} 0.35 \mathrm{~m}$ so that 720 stems of dwarf grass cuttings were needed, $270 \mathrm{~kg}$ of manure, $2.5 \mathrm{~kg}$ of NPK fertilizer. The method used was factorial pattern experiment with a randomized blok design. The first factor was manure consisting of $K_{0}$ : manure $0 \mathrm{~kg} / 5 \mathrm{~m}^{2}, K_{1}$ : manure $7,5 \mathrm{~kg} / 5 \mathrm{~m}^{2}, K_{2}:$ manure $15 \mathrm{~kg} / 5 \mathrm{~m}^{2}$ and the second factor was NPK $(M)$ fertilizer which consists of $M_{0}$ : NPK fertilizer $0 \mathrm{~g} / 5 \mathrm{~m}^{2}, M_{1}$ : NPK fertilizer 37,5 $\mathrm{g} / 5 \mathrm{~m}^{2}, M_{2}: N P K$ fertilizer $75 \mathrm{~g} / 5 \mathrm{~m}^{2}$ and $M_{3}: N P K$ fertilizer $112,5 \mathrm{~g} / 5 \mathrm{~m}^{2}$. The growth variables measured were height plant and number of leaves of third defoliation. The results of the analysis of variance showed that the interaction between the combination of manure and NPK was not significant effect $(P>0.05)$, while the manure application was highly significant effect $(P<0.01)$ on height plant and number of leaves, NPK fertilizer was significant effect $(P<0.05)$ of height plant and number of leaves of dwarf grass. The single effect of manure and NPK can significantly 
increased height plant and number of leaves. Interaction between manure and NPK was not significant effect on height plant and number of leaves $d$ warf grass.

Keywords: odot grass, manure, NPK, growth

\section{PENDAHULUAN}

Rumput odot (Pennisetum purpureum cv. Mott) merupakan satu spesies rumput berukuran mini yang memiliki tampilan hampir mirip dengan rumput gajah. Spesies rumput tersebut banyak diminati peternak karena mempunyai produktivitas dan kandungan nutrisi yang cukup tinggi. Rumput Odot memiliki keunggulan yaitu pertumbuhan cepat, berbulu halus, daun lembut, batang lunak, disukai ternak, regrowth (pertumbuhan kembali) yang cepat (Sirait, 2017).

Potensi rumput odot tersebut harus didukung oleh lahan yang subur. Kesuburan tanah atau lahan dapat dipertahankan dengan pemupukan. Pemberian pupuk anorganik secara terus menerus tidak dianjurkan karena dapat merusak sifat fisik, kimia, dan biologis tanah. Untuk mengatasi kekurangan pupuk anorganik tersebut dapat diatasi dengan pemberian pupuk organik.

Pupuk organik dapat berasal dari pelapukan sisa-sisa kotoran hewan, tumbuhan, dan manusia yang memiliki kandungan hara lebih lengkap walaupun dalam jumlah sedikit. Pupuk kandang mempunyai peranan yang cukup besar terhadap perbaikan sifat fisik, kimia, dan biologi tanah sedangkan NPK berfungsi meningkatkan kandungan unsur hara yang dibutuhkan tanaman dalam jumlah cukup banyak. Penggunaan kombinasi pupuk kandang dan NPK diharapkan dapat meningkatkan pertumbuhan dan produktivitas tanaman. Berdasarkan uraian tersebut maka penelitian mengenai pengaruh kombinasi pupuk kandang dan NPK pada tinggi tanaman dan jumlah daun rumput odot perlu dilakukan.

\section{METODOLOGI PENELITIAN}

Materi yang digunakan dalam penelitian adalah pupuk kandang $270 \mathrm{~kg}$, pupuk NPK $2,5 \mathrm{~kg}$, tanaman rumput odot defoliasi ke-3 yang awalnya ditanam 720 batang stek rumput odot (jarak tanam $0,75 \mathrm{~m} \times 0,35 \mathrm{~m}$ ) dan luas per petak/unit $\left(5 \mathrm{~m}^{2}\right)$ sehingga lahan yang digunakan seluas $278 \mathrm{~m}^{2}$. Masing-masing unit terdiri dari 20 stek rumput odot. Materi lainnya yaitu pita ukur, patok bambu, cangkul, sabit, sekop, karung, plastik, counter, metline, alat tulis. Metode penelitian adalah metode eksperimen menggunakan rancangan acak kelompok pola faktorial $3 \times$ 4, dengan 12 kombinasi perlakuan. Masing-masing perlakuan diulang 3 kali. Faktor pertama adalah pupuk kandang dengan 3 level yaitu $\mathrm{K}_{0}$ : pupuk kandang $0 \mathrm{~kg} / 5 \mathrm{~m}^{2}, \mathrm{~K}_{1}$ : pupuk kandang 7,5 kg/5m ${ }^{2}, \mathrm{~K}_{2}$ : pupuk kandang $15 \mathrm{~kg} / 5 \mathrm{~m}^{2}$ dan faktor kedua adalah pupuk NPK (M) dengan 4 level yaitu $\mathrm{M}_{0}$ : pupuk NPK $0 \mathrm{~g} / 5 \mathrm{~m}^{2}$, $\mathrm{M}_{1}$ : pupuk NPK $37,5 \mathrm{~g} / 5 \mathrm{~m}^{2}, \mathrm{M}_{2}$ : pupuk NPK $75 \mathrm{~g} / 5 \mathrm{~m}^{2}$ dan $\mathrm{M}_{3}$ : pupuk NPK $112,5 \mathrm{~g} / 5 \mathrm{~m}^{2}$. Penelitian telah dilaksanakan di Experimental Farm dan Laboratorium Agrostologi Fakultas Peternakan, Universitas Jenderal Soedirman, Purwokerto. Peubah pertumbuhan tanaman yang diamati dalam penelitian adalah tinggi tanaman dan jumlah daun. Data 
dianalisis statistik menggunakan analisis variansi dan diuji lanjut uji orthogonal polinomial (Steel dan Torrie, 1994).

Pengukuran tinggi tanaman dilakukan dengan cara mengukur tinggi tanaman dari atas permukaan tanah sampai ke ujung tanaman menggunakan metline, sedangkan untuk jumlah daun diperoleh dari daun yang telah terbentuk sempurna dihitung jumlah daunnya dalam satuan helai menggunakan alat bantu counter dilakukan 3 hari sebelum defoliasi rumput odot.

\section{HASIL DAN PEMBAHASAN}

\section{Pengaruh Kombinasi Pupuk Kandang dan NPK pada Tinggi Tanaman Rumput Odot (Pennisetum purpureum cv. Mott)}

Tinggi tanaman merupakan salah satu indikator pertumbuhan tanaman rumput odot. Semakin tinggi tanaman dapat dikatakan bahwa tanaman tersebut subur dan memiliki produksi yang tinggi. Hasil pengukuran tinggi tanaman dari kombinasi pemberian pupuk kandang dengan NPK didapat hasil nilai rata-rata yang meningkat. Hasil rataan terendah pada tinggi tanaman terdapat pada perlakuan $\mathrm{K}_{1} \mathrm{M}_{0} 70,00 \pm 10,24 \mathrm{~cm}$, sedangkan rataan tertinggi pada perlakuan $\mathrm{K}_{2} \mathrm{M}_{2}$ dan $\mathrm{K}_{2} \mathrm{M}_{3}$ yaitu sebesar 80,27 $\pm 10,48 \mathrm{~cm}$ dan 80,89 $\pm 8,91$ $\mathrm{cm}$. Kisaran tinggi tanaman rumput odot yaitu 76,19-85,70 cm. Data selengkapnya tertera pada Tabel 1. Tinggi tanaman ini relatif sebanding dengan penelitian Halim et al., (2013) setinggi $79 \mathrm{~cm}$ namun lebih rendah dibandingkan dengan penelitian Lasamadi dkk., (2013) setinggi 108,2-125,4 cm. maupun yang ditemukan oleh Budiman et al., (2012) setinggi $104,75-126,01 \mathrm{~cm}$.

Tabel 1. Rataan Hasil Tinggi Tanaman Rumput Odot (cm)

\begin{tabular}{cccccc}
\hline \multirow{2}{*}{$\begin{array}{c}\text { Pupuk } \\
\text { Kandang }\end{array}$} & \multicolumn{4}{c}{ Pupuk NPK } & \multirow{2}{*}{ Rataan } \\
\cline { 2 - 5 } & M0 & M1 & M2 & M3 & \\
\hline K0 & $73,28 \pm 6,33$ & $76,05 \pm 8,41$ & $76,22 \pm 8,33$ & $79,22 \pm 6,06$ & $76,19 \pm 6,66$ \\
K1 & $70,00 \pm 10,24$ & $73,83 \pm 0,76$ & $75,39 \pm 9,55$ & $74,67 \pm 6,23$ & $73,47 \pm 6,89$ \\
K2 & $79,44 \pm 9,14$ & $85,38 \pm 9,02$ & $89,22 \pm 9,91$ & $88,87 \pm 9,29$ & $85,70 \pm 8,95$ \\
\hline Rataan & $74,24 \pm 8,62$ & $78,42 \pm 8,14$ & $80,27 \pm 10,48$ & $80,89 \pm 8,91$ & \\
\hline
\end{tabular}

Tabel 2. Analisis Variansi Tinggi Tanaman Rumput Odot

\begin{tabular}{lcrrrrr}
\hline \multicolumn{1}{c}{$\begin{array}{c}\text { Sumber } \\
\text { Variansi }\end{array}$} & $\begin{array}{c}\text { Derajat } \\
\text { Bebas }\end{array}$ & $\begin{array}{c}\text { Jumlah } \\
\text { Kuadrat }\end{array}$ & $\begin{array}{c}\text { Kuadrat } \\
\text { Tengah }\end{array}$ & F Hitung & \multicolumn{2}{c}{ F Tabel } \\
\cline { 6 - 7 } & 2 & 1219,9127 & 609,9563 & $43,7809 * *$ & 3,44 & 5,72 \\
Blok & 11 & 1278,3679 & 116,2153 & $6,6268^{* *}$ & 2,26 & 3,18
\end{tabular}


Jurnal Sains Peternakan Nusantara Pertumbuhan Rumput Odot di Bawah Pengaruh Kombinasi Pupuk

EISSN: 2807-9361

Volume 01 Nomor 02 Desember 2021

\begin{tabular}{|c|c|c|c|c|c|c|}
\hline $\mathrm{K}$ & 2 & 989,9808 & 494,9904 & $28,2253 * *$ & 3,44 & 5,72 \\
\hline $\mathrm{K} \operatorname{lin}$ & 1 & 542,9259 & 542,9259 & $30,9587 * *$ & 4,30 & 7,95 \\
\hline $\mathrm{K} \mathrm{kdr}$ & 1 & 447,0548 & 447,0548 & $25,4920 * *$ & 4,30 & 7,95 \\
\hline M & 3 & 243,1814 & 81,0605 & $4,6222^{*}$ & 3,05 & 4,82 \\
\hline$M \operatorname{lin}$ & 1 & 213,9452 & 213,9452 & $12,1996 * *$ & 4,30 & 7,95 \\
\hline M kdr & 1 & 28,6939 & 28,6939 & 1,6362 & 4,30 & 7,95 \\
\hline M kbk & 1 & 0,5423 & 0,5423 & 0,0309 & 4,30 & 7,95 \\
\hline $\mathrm{K} \times \mathrm{M}$ & 6 & 45,2057 & 7,5343 & 0,4296 & 2,55 & 3,76 \\
\hline Error & 22 & 385,8160 & 17,5371 & & $\mathrm{SD}=$ & 4,188 \\
\hline Total & 35 & 2884,0966 & & & $\begin{aligned} & \mathrm{KK} \\
= & \end{aligned}$ & $5,337 \%$ \\
\hline
\end{tabular}

Keterangan $: *=$ berpengaruh nyata $(\mathrm{P}<0,05), * *=$ berpengaruh sangat nyata $(\mathrm{P}<0,01)$

Hasil analisis variansi menunjukan bahwa pemberian pupuk kandang berpengaruh sangat nyata $(\mathrm{P}<0,01)$ terhadap tinggi tanaman. Pemberian NPK juga berpengaruh nyata $(\mathrm{P}<0,05)$ terhadap tinggi tanaman lihat Tabel 2. Hal tersebut sesuai pendapat Kusuma (2014) bahwa pemberian pupuk majemuk memberikan pengaruh yang nyata terhadap pertumbuhan dan produksi. Unsur hara makro seperti N, P, dan K sangat dibutuhkan oleh tanaman.

Nitrogen merupakan bahan penyusun asam amino, amida, basa nitrogen seperti purin, dan protein serta nukleoprotein. Defisiensi $\mathrm{N}$ membatasi pembesaran sel dan pembelahan sel. Gejala defisiensi meliputi pertumbuhan umum yang berbentuk kerdil dan kuning. Phospor merupakan bahan dasar penyusun fosfolipid. Gejala kekurangan P yang tampak daun berwarna hijau gelap atau hijau kebiru-biruan, tanaman juga kerdil. Kalium penting bagi tanaman tingkat tinggi dan tingkat rendah. Kalium sangat perperan penting dalam fotosintesis karena secara langsung berpengaruh secara langsung terhadap pertumbuhan tanaman (Gardner dan Peare, 1985). 


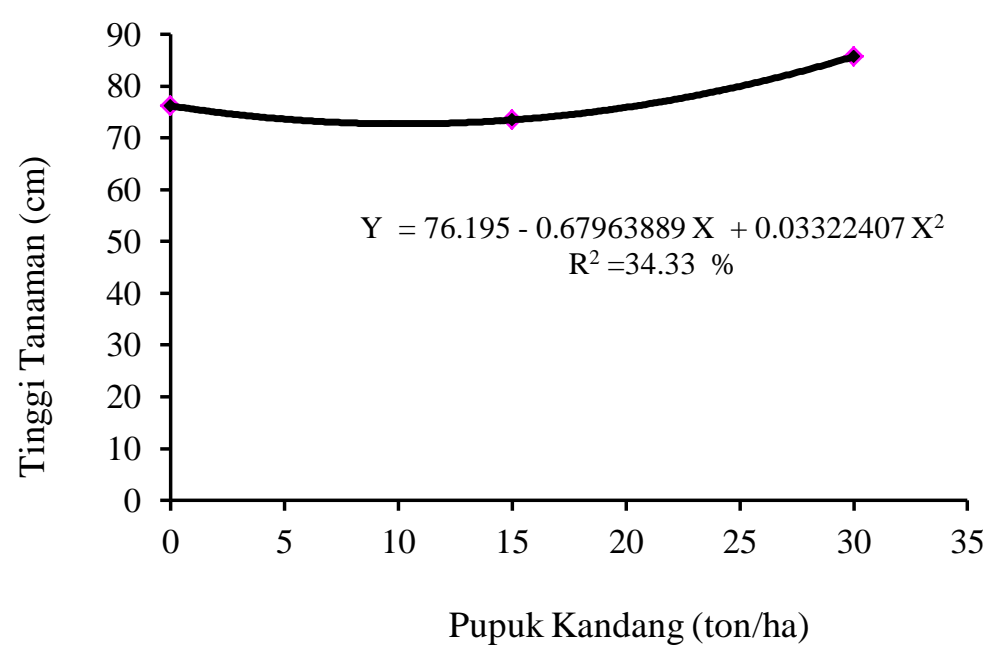

Gambar 1. Grafik hubungan antara level pupuk kandang dengan tinggi tanaman rumput odot

Hasil uji orthogonal polinomial (Gambar 1) menunjukkan level pemberian pupuk kandang berpengaruh secara kuadratik terhadap tinggi tanaman rumput odot dengan persamaan $\mathrm{Y}=76,195-0,067963889 \mathrm{X}+0,03322407 \mathrm{X}^{2}$ dengan koefisien determinasi $\left(\mathrm{R}^{2}\right)=34,33 \%$ artinya level pupuk kandang yang berpengaruh terhadap tinggi tanaman sebesar 34,33 \% sedangkan sisanya 65,67 \% dipengaruhi faktor lainnya.

Level pemberian pupuk NPK berpengaruh secara linier terhadap tinggi tanaman rumput odot dengan persamaan $\mathrm{Y}=75,188778+0,02907259 \mathrm{X}$ dengan koefisien determinasi $\left(\mathrm{R}^{2}\right)=7.42 \%$ artinya level pupuk NPK yang berpengaruh terhadap tinggi tanaman sebesar 7,42\% sedangkan sisanya $92,58 \%$ dipengaruhi oleh faktor lainnya. Hasil penelitian menunjukan bahwa penggunaan pupuk kandang dan pupuk NPK dapat meningkatkan produksi tanaman ditinjau dari tinggi tanaman. Hal ini dikarenakan unsur hara dalam tanah akan meningkat jika diberi pupuk kandang dan NPK, terutama pupuk kandang yang mempunyai kelebihan memperbaiki struktur tanah, meningkatkan sifat biologi, fisik dan kimia tanah, selain itu pupuk NPK memiliki sifat yang lebih cepat larut (Qohar et al., 2020; Hendarto et al., 2020; Qohar et al., 2019; Qohar, et al., 2021; Qohar, et al., 2021). Menurut Lingga (2000) bahwa untuk memperoleh pertumbuhan dan produksi yang optimum maka hara dalam tanah harus tersedia supaya tanaman mendapatkan unsur hara yang cukup dan seimbang. 


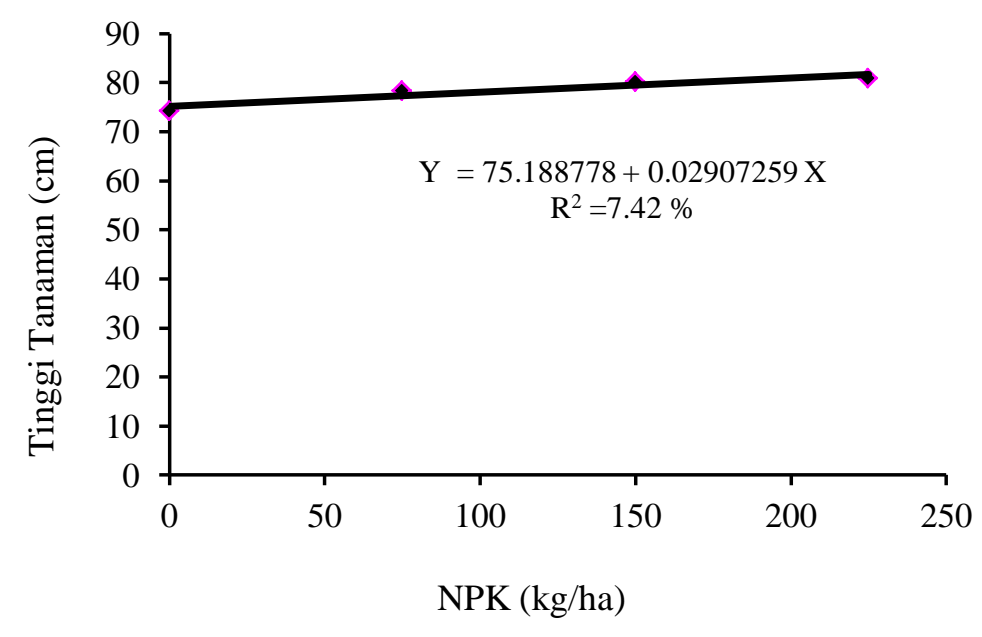

Gambar 2. Grafik hubungan antara level pupuk NPK dengan tinggi tanaman rumput odot

\section{Pengaruh Kombinasi Pupuk Kandang dan NPK Pada Jumlah Daun Rumput Odot (Pennisetum purpureum cv. Mott)}

Hasil penelitian penggunaan kombinasi pupuk kandang dengan NPK terhadap rataan jumlah daun rumput odot disajikan pada Tabel 3. Tabel 3 menunjukkan rataan jumlah daun paling rendah tanaman rumput odot pada perlakuan $\mathrm{K}_{1} \mathrm{M}_{0}$ sebesar $46,72 \pm$ 15,23 helai per rumpun, sedangkan jumlah daun tertinggi terdapat pada perlakuan $\mathrm{K}_{2} \mathrm{M}_{2}$ sebesar 116,05 $\pm 28,48$ helai per rumpun. Hasil penelitan hampir sama dengan penelitian Dewi (2017) sebanyak 77,8 helai/rumpun dan penelitian Kusuma (2014) sebanyak 54,380,2 helai/rumpun. Hasil tersebut menunjukan bahwa rataan jumlah daun tertinggi terdapat pada perlakuan yang diberi pupuk kandang dan NPK. Hal ini berbeda dengan penelitian Dewi (2017) bahwa jumlah daun tertinggi diperoleh dari perlakuan kontrol tanpa pupuk. Unsur hara $\mathrm{N}$ berfungsi untuk pertumbuhan tanaman sehingga apabila unsur hara tersebut terpenuhi maka produksi yang dihasilkan akan meningkat. Hal tersebut sesuai dengan pendapat Kusuma (2014) bahwa unsur N berfungsi sebagai pertumbuhan tanaman sehingga kebutuhannya akan semakin meningkat dengan bertambahnya umur tanaman tersebut.

Tabel 3. Rataan Hasil Jumlah Daun Rumput Odot (helai/rumpun)

\begin{tabular}{lccccc}
\hline \multirow{2}{*}{$\begin{array}{c}\text { Pupuk } \\
\text { Kandang }\end{array}$} & \multicolumn{4}{c}{ Pupuk Majemuk } & \multirow{2}{*}{ Rataan } \\
\cline { 2 - 5 } & M0 & M1 & M2 & M3 & \\
\hline K0 & $58,77 \pm 14,00$ & $57,72 \pm 8,95$ & $68,44 \pm 13,54$ & $70,88 \pm 13,74$ & $63,95 \pm 12,42$ \\
K1 & $46,72 \pm 15,23$ & $68,83 \pm 9,20$ & $69,89 \pm 3,09$ & $93,55 \pm 32,75$ & $69,75 \pm 23,53$ \\
K2 & $77,00 \pm 50,68$ & $105,44 \pm 32,97$ & $116,05 \pm 28,48$ & $94,83 \pm 29,83$ & $98,33 \pm 34,65$ \\
\hline Rataan & $60,83 \pm 30,38$ & $77,33 \pm 27,93$ & $84,79 \pm 28,30$ & $86,43 \pm 25,96$ & \\
\hline
\end{tabular}


Hasil analisis variansi menunjukan bahwa pemberian pupuk kandang berpengaruh sangat nyata $(\mathrm{P}<0,01)$ terhadap jumlah daun rumput odot. Sedangkan pemberian pupuk NPK berpengaruh nyata $(\mathrm{P}<0,05)$ terhadap jumlah daun rumput odot lihat Tabel 4 . Hal tersebut karena di dalam pupuk kandang maupun pupuk NPK terdapat unsur phospor berfungsi untuk pertumbuhan dan perkembangan tanaman. Hal tersebut sesuai sependapat dengan Sutejo (2002) bahwa phospor berfungsi untuk mempercepat pertumbuhan, mempercepat dan memperkuat pertumbuhan tanaman, mempercepat pembungaan.

Tabel 4. Analisis Variansi Jumlah Daun Rumput Odot

\begin{tabular}{|c|c|c|c|c|c|c|}
\hline \multirow{2}{*}{$\begin{array}{l}\text { Sumber } \\
\text { Variansi }\end{array}$} & \multirow{2}{*}{$\begin{array}{c}\text { Derajat } \\
\text { Bebas }\end{array}$} & \multirow{2}{*}{$\begin{array}{l}\text { Jumlah } \\
\text { Kuadrat }\end{array}$} & \multirow{2}{*}{$\begin{array}{l}\text { Kuadrat } \\
\text { Tengah }\end{array}$} & \multirow{2}{*}{ F Hitung } & \multicolumn{2}{|c|}{ F Tabel } \\
\hline & & & & & 0,05 & 0,01 \\
\hline Blok & 2 & 6241,7367 & 3120,8683 & $8,0132 * *$ & 3,44 & 5,72 \\
\hline Perlakuan & 11 & 14319,7045 & 1301,7913 & $3,3425 * *$ & 2,26 & 3,18 \\
\hline K & 2 & 8129,0317 & 4064,5158 & $10,4361 * *$ & 3,44 & 5,72 \\
\hline $\mathrm{K}$ lin & 1 & 7090,1875 & 7090,1875 & $18,2048^{* *}$ & 4,30 & 7,95 \\
\hline $\mathrm{K} \mathrm{kdr}$ & 1 & 1038,8442 & 1038,8442 & 2,6673 & 4,30 & 7,95 \\
\hline M & 3 & 3695,3901 & 1231,7967 & $3,16288^{*}$ & 3,05 & 4,82 \\
\hline$M \operatorname{lin}$ & 1 & 3193,1172 & 3193,1172 & $8,1987 * *$ & 4,30 & 7,95 \\
\hline M kdr & 1 & 497,6617 & 497,6617 & 1,2778 & 4,30 & 7,95 \\
\hline M kbk & 1 & 4,6112 & 4,6112 & 0,0118 & 4,30 & 7,95 \\
\hline $\mathrm{K} \times \mathrm{M}$ & 6 & 2495,2827 & 415,8804 & 1,0678 & 2,55 & 3,76 \\
\hline Error & 22 & 8568,2802 & 389,4673 & & $\mathrm{SD}=$ & 19,735 \\
\hline Total & 35 & 29129,7214 & & & $\mathrm{KK}=$ & 25,5159 \\
\hline
\end{tabular}

Keterangan : ${ }^{*}=$ berpengaruh nyata $(\mathrm{P}<0,05),{ }^{* *}=$ berpengaruh sangat nyata $(\mathrm{P}<0,01)$

Hasil uji orthogonal polinomial (Gambar 3) menunjukkan bahwa pemberian pupuk kandang berpengaruh secara linear terhadap jumlah daun rumput odot dengan persamaan $\mathrm{Y}=60,159028+1,1458611 \mathrm{X}$ dengan koefisien determinasi $\left(\mathrm{R}^{2}\right)=23,34 \%$ artinya level pupuk kandang yang berpengaruh terhadap jumlah daun rumput odot sebesar $23,34 \%$ sedangkan sisanya $76,66 \%$ di pengaruhi oleh faktor lainnya. 


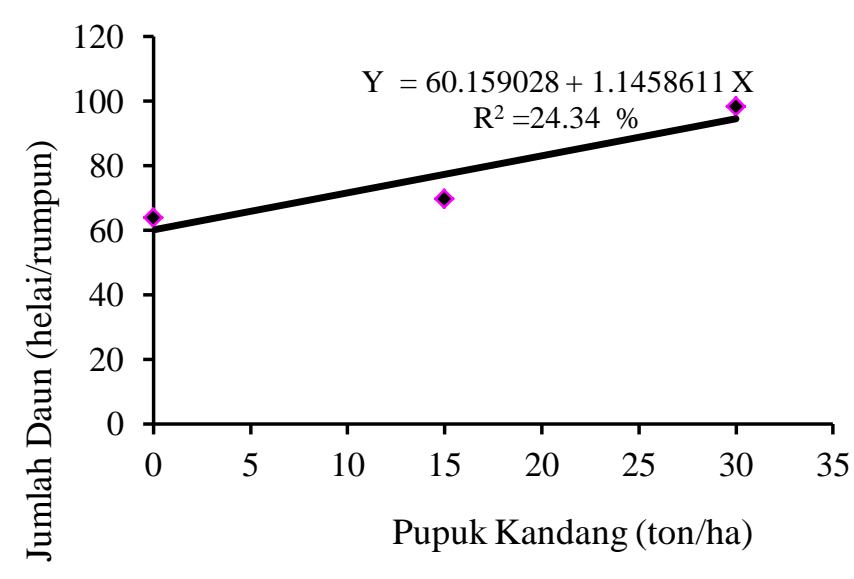

Gambar 3. Grafik hubungan antara level pupuk kandang dengan jumlah daun rumput odot

Pemberian pupuk NPK berpengaruh secara linear terhadap jumlah daun rumput odot dengan persamaan $\mathrm{Y}=64,711444+0,11231556 \mathrm{X}$ dengan koefisien determinasi $\left(\mathrm{R}^{2}\right)$ $=10,96 \%$ artinya level pupuk NPK yang berpengaruh terhadap tinggi tanaman sebesar 10,96\% sedangkan sisanya 89,04\% dipengaruhi oleh faktor lainnya. Berdasarkan hasil uji orthogonal polinomial (gambar 4) dapat diketahui bahwa level pupuk NPK yang semakin tinggi akan meningkatkan jumlah daun rumput odot. Hal tersebut disebabkan karena pupuk NPK lebih cepat larut sehingga penyerapan unsur hara juga akan lebih cepat.

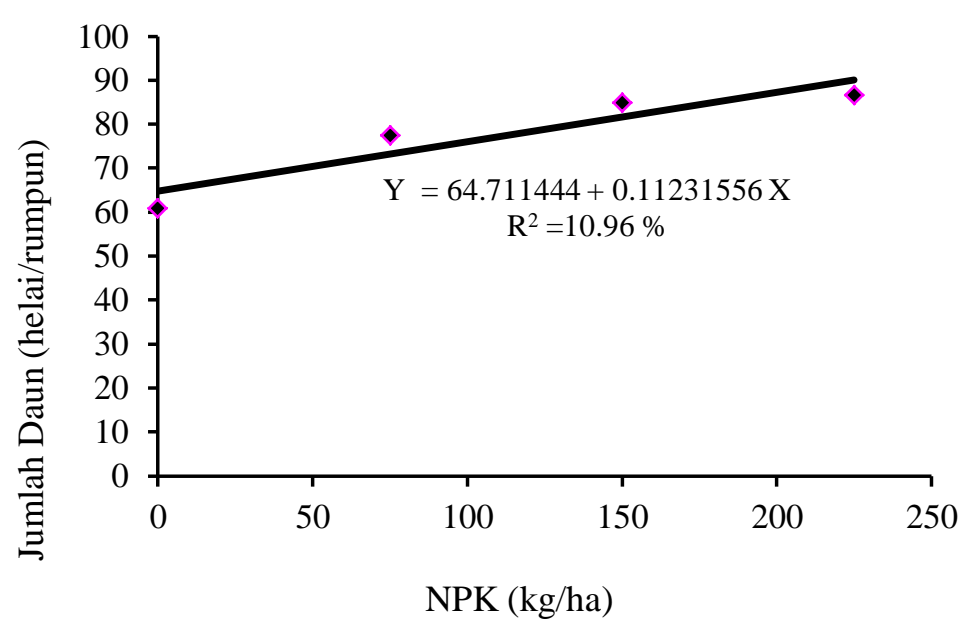

Gambar 4. Grafik hubungan antara level pupuk NPK dengan jumlah daun rumput odot

\section{KESIMPULAN}

Interaksi antara pupuk kandang dan NPK tidak memberikan pengaruh yang nyata terhadap tinggi tanaman dan jumlah daun. Semakin tinggi level pupuk kandang dan NPK akan meningkatkan pertumbuhan tinggi tanaman dan jumlah daun rumput odot. 
Jurnal Sains Peternakan Nusantara Pertumbuhan Rumput Odot di Bawah Pengaruh Kombinasi Pupuk EISSN: 2807-9361

Volume 01 Nomor 02 Desember 2021

\section{DAFTAR PUSTAKA}

Budiman, R. D, Sutrisna, S. P. S Budhi, dan A. Indrianto. (2012). Morphological Characteristics, Productivity and Quality Of Three Napier Grass (Pennisetum Purpureum Schum) Cultivars Harvested at Different Age. Jurnal Indonesia Tropic Animal Agriculture. 37: 294-301.

Dewi, D. P. R. (2017). Produksi Rumput (Pennisetum purpureum cv. Mott) Defoliasi Pertama dengan Jenis Pupuk yang Berbeda. Jurnal Aves. 11(2), 61-70.

Gardner, F. P. dan Peare R. B. (1985). Physiologi of Crop Plants. Penerjemahan H. Susilo. Fisiologi Tanaman Budidaya. UI Press. Jakarta.

Halim, R. Shampazuraini, A., Idris, A. B. (2013). Yield and Nutritive quality of nine napier grass varietas in Malaysia. Malaysia Jurnal Animal Science. 16(2), 37-44.

Kusuma, M. E. (2014). Respon Rumput Gajah (Pennisetum purpureum) pada Pemberian Pupuk Majemuk. Jurnal Ilmu Hewani Tropika. 3(1),6-11.

Lasamadi, R. D., Malalantang, S. Rustandi, S., dan Anis, S. D. (2013). Pertumbuhan dan Perkembangan Rumput Gajah Dwarf (Pennisetum purpureum cv. Mott) yang Diberi Pupuk Organik Hasil Fermentasi EM4. Jurnal Zootek. 32(5),158-171.

Lingga, P. 2000. Petunjuk Penggunaan Pupuk. Penebar Swadaya. Jakarta.

Qohar A. F, Hendarto E. \& Munasik. (2020). Pertumbuhan Rumput Raja (Pennisetum purpureophoides) Defoliasi Kedua Akibat Pemupukan Kompos yang Diperkaya dengan Azolla microphylla. Prosiding Seminar Nasional Pembangunan Dan Pendidikan Vokasi Pertanian, 1(1), 1-9. https://doi.org/10.47687/snppvp.v1i1.120

Hendarto, E., Qohar, A. F., Hidayat, N. \& ... (2020). Produksi Dan Daya Tampung Rumput Odot (Pennisetum purpureum cv. Mott) Pada Berbagai Kombinasi Pupuk Kandang Dan NPK. Prosiding Seminar Teknologi Dan Agribisnis Peternakan VII-Webinar: Prospek Peternakan Di Era Normal Baru Pasca Pandemi COVID-19, 7(7), 751758.

Qohar, A. F., Hendarto, E. \& Hidayat, N. (2021). Dynamics Effect of Compost Fertilizer Dose and Enrichment of Azolla on the Growth of King Grass. Annals of the Romanian Society for Cell Biology, 25(4), 20296-20303.

Qohar, A. F., Hendarto, E., Hidayat, N., Bahrun, Harwanto \& Nuraeni, N. (2021). Pengaruh Kombinasi Dosis Pemupukan Kompos Organik Dan Penambahan Azolla Terhadap Pertumbuhan Rumput Raja. Jurnal Sains Peternakan Nusantara, 01(01), $1-12$.

Qohar, A. F., Hidayat, N. \& Bahrun, B. (2019). Pengaruh Kombinasi Pupuk Kandang Dan NPK Terhadap Tinggi Tanaman Dan Jumlah Daun Rumput Odot (Pennisetum purpureum cv. Mott). Journal of Livestock and Animal Production, 2(1), 1-7. 
Jurnal Sains Peternakan Nusantara Pertumbuhan Rumput Odot di Bawah Pengaruh Kombinasi Pupuk EISSN: 2807-9361 Volume 01 Nomor 02 Desember 2021

Sirait, J. 2017. Rumput Gajah Mini (Pennisetum Purpureum cv. Mott) sebagai Hijauan Pakan untuk Ruminansia. Wartazoa. 27(4):167-176.

Steel, R. G. D dan J. H. Torrie. (1994). Principle and Procedures of Statistics: A Biometrical Approach. Terjemahan:B. Soemantri. Prinsip dan Prosedur Statistika (Pendekatan Biometrik) . PT. Gramedia Pustaka Utama. Jakarta.

Sutejo, M. M. (2002). Pupuk dan Cara Pemupukan. Cetakan ke-7. Rineka Cipta. Jakarta. 